\title{
Reply: Whither the Parallel Paths? The Future of Scholarship on the World City System
}

\section{Citation}

Beckfield, Jason, and Arthur S. Alderson. 2006. "Reply: Whither the Parallel Paths? The Future of Scholarship on the World City System." American Journal of Sociology 112 (3) (November): 895-904. doi:10.1086/510992.

\section{Published Version}

http://dx.doi.org/10.1086/510992

\section{Permanent link}

http://nrs.harvard.edu/urn-3:HUL.InstRepos:34708492

\section{Terms of Use}

This article was downloaded from Harvard University's DASH repository, and is made available under the terms and conditions applicable to Other Posted Material, as set forth at http:// nrs.harvard.edu/urn-3:HUL.InstRepos:dash.current.terms-of-use\#LAA

\section{Share Your Story}

The Harvard community has made this article openly available.

Please share how this access benefits you. Submit a story.

\section{Accessibility}




\section{REPLY: WHITHER THE PARALLEL PATHS? THE FUTURE OF SCHOLARSHIP ON THE WORLD CITY SYSTEM ${ }^{1}$}

We thank Peter Taylor for his insightful and even-handed comments. We agree that our work and the research of the Globalization and World Cities (GaWC) Study Group and Network have much to add to one another, and we see a bright future ahead for interdisciplinary world city research. We are grateful for the opportunity to respond, and we would like to use this rejoinder to take the next step toward that future by envisioning inquiry that builds on the complementarities of our two approaches. Of course, we also respond to the critical points Taylor raises. In what follows, we first address these points, then further sharpen some of the differences between the GaWC approach and our own. We conclude with a discussion of how scholarship that combines the strengths of these approaches might proceed.

\section{TAYLOR'S CRITIQUE}

In contrasting our respective approaches to global intercity relations, Taylor is generous in his assessment of the strengths of our approach; he is just as quick to note the comparative points of weaknesses in his own work as he is to note those in ours. We differ with only a few of the points that he raises and believe that it would be most productive and illuminating to respond to four of his concerns: (1) that in applying some of the techniques that we draw from social network analysis to the study of the world city system, our approach risks reifying cities and, thereby, obscuring the economic agency of firms, (2) that Taylor's approach relates cities to firms in a more subtle or sensitive fashion than our approach, (3) that our approach misses "regional headquarters," and (4) that we mistake "network power" for prestige.

The kernel of Taylor's first concern is that, at points, our approach appears to have uncomfortable ontological implications. He is particularly concerned with our interpretation of our results for indegree, which sug-

${ }^{1}$ We thank Jocelyn Viterna and Saskia Sassen for their comments. This research was supported by a grant to Alderson from the World Society Foundation. Direct correspondence to Jason Beckfield, Department of Sociology, University of Chicago, 1126 East Fifty-ninth Sreet, Chicago, Illinois 60637. E-mail: jbeckfie@uchicago.edu or aralders@indiana.edu

Permission to reprint a contribution from this section must be obtained from the essay's author. 
American Journal of Sociology

gests a system in which cities have prestige and in which acts of deference are commonplace. Taylor believes that such language, rooted in social network analysis, may be appropriate for networks of individuals, but is "problematic" (in this issue, p. 886) or simply "unhelpful" (in this issue, p. 888) for networks of cities, especially, he suggests, as it conceals the economic agents-the multinational enterprises-that knit together the world city system. We have three responses. First, we think it theoretically informative to treat cities as actors embedded in networks of relations. Second, our approach in fact preserves the economic agency of the firm, but in a way that differs from Taylor's interlocking model. Third, we do not believe it necessarily inappropriate to talk about the world city system, or other social things, in such terms.

Theoretical approaches to world cities postulate a network of cities and imply specific hypotheses about the morphology of the world city system (Alderson and Beckfield 2004, pp. 814-19). Operationalizing the world city system as a network allows the identification of cities that sit atop the urban hierarchy, by virtue of the nature of their ties to other cities. The proof of the pudding is not just in results, it is also in theoretical utility: Treating cities as nodes in networks allows us to assess contending visions of the world city system. As Taylor rightly notes, network-analytic tools were developed in the empirical context of individuals in small groups (Moreno 1934), but social scientists have since extended the application of social network analysis to families (Padgett and Ansell 1993), academic departments (Burris 2004), organizations (Fernandez and Gould 1994; Powell, White, Koput, and Owen-Smith 2005), subnational regions (Meyer 1984), and nation-states (Kim and Shin 2002; Smith and White 1992; Snyder and Kick 1979). Analysis of the structure and dynamics of such networks raises, to our minds, no special philosophical issues and, indeed, can generate distinctive insights into the behavior of the "lowerorder" elements that form them. In short, it is useful to think of cities in networks of interaction for the same reason that it is useful to think of everything from genes and neurons to nation-states and civilizations in networks of interaction.

While we are careful at a number of points in our article to stress that multinational enterprises generate the network that we study, it is worth emphasizing that what we ultimately analyze is not a network of firms, but a network of cities produced by the location decisions of firms. In our approach - and in the most recent version of the GaWC approach as well (see below) - firms plainly constitute cities (i.e., cities literally do not appear in either network unless firms tie them to other cities). As such, rather than being, as Taylor claims, "lost to the analysis in the creation of the city $\times$ city matrix for social network analysis" (p. 886), firms, or, more correctly, the results of the "economic agency" of firms, are precisely 
what we analyze. At the same time, however, the product of that agency is a network of cities, a network with distinct structural properties that can be analyzed in their own right. The structure of the network of cities linked by firms is not, for instance, the simple mirror image of that of the network of firms linked by cities.

To illustrate, consider, for example, research on corporate interlocks. In analyzing interlocking directorates, researchers typically examine the network of firms linked by directors. But one could also examine the network of directors linked by firms. Both, of course, are intimately related and, indeed, given knowledge of the former, one can derive the latter (and vice versa) (Breiger 1974; McPherson 1982). However, as Burris (2004, p. 253) notes, "there is no simple correspondence between the structural properties of a network and its dual." Burris illustrates this point with Bearden and Mintz's (1987) study of corporate class cohesion in the United States. Analyzing the network of corporations linked by directors, they find that banks play a central role in integrating corporations. Analyzing the network of directors linked by corporations, in contrast, they find that bankers themselves do not play an equivalent role in integrating directors.

In the course of serving on boards, directors thus generate two distinct networks: an interdirector network and an intercorporate network. Directors are plainly there in both, but in the former, directors are nodes and the corporations that directors share are ties, while in the latter corporations are nodes and the directors that corporations share are ties. Similarly, in our research, in the course of making location decisions, multinational firms generate an interfirm network and an intercity network. Multinationals are there in both, but in the former, firms are nodes and the cities that firms share are ties, while in the latter cites are nodes and the firms that cities share are ties.

The nub is that corporations are also there in both director-generated networks, just as cities are also there in both of the multinational-generated networks. Thus if we take seriously the key premise of research on "world" or "global" cities-that cities, like the corporations of interlock research, should be understood relationally - then the claim that some cities are more prestigious than others or that some cities defer to others should be considered no more exotic than the idea that firms can form cliques or that banks can act to unify a corporate structure. Prestige and deference, like clique and cohesion, are relational concepts that can be employed to describe networks regardless of their specific content, and at no risk of reifying the nodes. Indeed, rather than reifying cities, our approach highlights the fundamental duality of firms and cities implied in nearly all thinking on the world city system: while we agree with Taylor that world cities are not independent of the firms (and other actors) that 


\section{American Journal of Sociology}

create them, neither our Global 500 nor Taylor's advanced producer service firms are independent of the world cities in which they have a stake. ${ }^{2}$

Taylor's second concern is motivated by a desire to further foreground the firm as a creative agent that knits world cities together through location decisions-especially "the attraction of advanced producer service firms . . . to major cities" (in this issue, pp. 884-85). As he notes, our approach and the GaWC approach operationalize ties among cities differently, producing distinct data matrices. Taylor's "interlocking network model" is based on the analysis of a bimodal network, meaning that the network includes two types of actors: here, cities and firms. ${ }^{3}$ Our network analysis uses a unimodal network, meaning that the network includes only cities. Concretely, then, the difference is between a matrix (call it "GaWC") where the rows indicate cities, the columns indicate firms, and the values in the cells indicate the strength of the presence of firm $j$ in city $i$, vs. a matrix (call it "A/B") where both rows and columns indicate cities, and the values in the cells indicate the number of firms in city $i$ that have subsidiaries in city $j$. The GaWC matrix does foreground firms, but, as demonstrated above, firms are also present in the A/B matrix. Both matrices ultimately yield rankings of cities that are based on the patterns of ties among firms located in cities, but a distinct advantage of the GaWC matrix is its more sensitive treatment of the precise strength of the presence of firm $j$ in city $i$. The $\mathrm{A} / \mathrm{B}$ matrix, on the other hand, measures the strength of connections among cities-or capacities of control-as the number of firms with headquarter-subsidiary relations involving the relevant cities.

Where the GaWC matrix represents "service values" as a firm-specific relation, the A/B matrix aggregates total command and control across firms. For instance, the A/B matrix shows that New York firms have 73 subsidiaries in Los Angeles, while Los Angeles firms have 26 subsidiaries in New York. We interpret this as evidence that New York has greater command capacity over Los Angeles than Los Angeles has over New York. It is certainly the case that specific instantiations of command and control happen in firms, but we believe that it is the cross-firm capacity for command and control that makes a difference for cities and for "worldcityness." Interestingly enough, in the final analysis, our respective approaches do not differ on this point. While the GaWC matrix differs from

\footnotetext{
${ }^{2}$ Our approach obviously owes much to Simmel (1964) and Breiger (1974) but is also informed by organizational research in the line from Stinchcombe (1965) to DiMaggio (1986) and Hannan and Freeman (1989), which suggests that organizations constitute fields and niches, but are also constituted by them, such that information on organizations can be used to define and analyze organizational space (just as information on organizational space can be used to define and analyze organizations).

${ }^{3}$ On bimodal networks, see Borgatti and Everett (1997).
} 
the $\mathrm{A} / \mathrm{B}$ matrix in retaining information on individual firms, that information is not retained in the ranking of cities on "interlock connectivity" (Taylor, in this issue, p. 886). A city's connectivity is measured by "summing the products of every firm's service value in the city with their service values in all other cities" (Taylor, in this issue, p. 886). In summing the products, information on service values of specific firms is "lost," just as is information on the headquarters and subsidiaries of specific multinationals in our approach. But this is as it should be, given that what we are both after is "the importance of a city within the network" (Taylor, in this issue, p. 887). ${ }^{4}$

Taylor's third concern is that our attention to headquarter-subsidiary relations undervalues cities that serve as "regional headquarters," as they are strictly characterized as subsidiaries in our data. For instance, the headquarters of ABN-AMRO North America, located in Chicago, is coded as a subsidiary of ABN-AMRO Holding N.V., headquartered in Amsterdam. But ABN-AMRO North America itself has subsidiaries in Atlanta, Boston, Houston, Los Angeles, Miami, New York, Pittsburgh, San Francisco, and Seattle. Incorporating information on middle-level relations like this by allowing for variation in the level of presence of firm $j$ in city $i$ is, we agree, another distinct advantage of the GaWC approach. Our approach captures these middle-level relations only indirectly. Staying with the example of ABN-AMRO, although we do not code the ChicagoHouston tie as a headquarter-subsidiary relation, we do include the headquarter-subsidiary ties of other firms with head offices in Chicago (e.g., both Sara Lee and Bank One had headquarters in Chicago and subsidiaries in Houston in 2000). Thus, at the level of the city network, our approach recognizes cities like Chicago as both powerful headquarter cities and prestigious subsidiary cities, while being insensitive to the level of importance of locations for individual firms.

Finally, Taylor is concerned that we view the cross-firm aggregation of subsidiaries in a city as prestige. He argues that this should be recast as "network power" (in this issue, p. 890). Here, we think, Taylor may not fully appreciate our intentions in examining the closeness and betweenness

${ }^{4}$ This is illustrated in an example presented in World City Network: A Global Urban Analysis (Taylor 2004, p. 64). The advertising firm TMP has a medium-size office ("service value" $=2$ ) in Chicago and a large office ("service value" = 3) in New York. The law firm Sidley \& Austin has large offices in both cities. To calculate the city interlock between Chicago and New York, the service values are first multiplied together, so that the service value of TMP's connection between Chicago and New York is $(2 \times 3=6)$ and the service value of Sidley \& Austin's Chicago-New York tie is $(3 \times 3=9)$. So far, the individual firms remain in the data. But the next step toward ranking cities sums these service values across firms, so that the Chicago-New York tie is coded $(6+9=15)$. These cross-firm sums are the elements of the matrix used in the calculation (and ranking) of interlock connectivity. 


\section{American Journal of Sociology}

of cities, in addition to their outdegree and indegree. Given that there are multiple senses in which network position might yield advantage or disadvantage, and given that these include precisely what Taylor describes as "power as a medium," we thought it important to look beyond what he calls "power as capacity or domination" (in this issue, p. 890; see Alderson and Beckfield 2004, pp. 822-24). The relative "network power" of a Barcelona versus an Omaha (see Taylor, in this issue, p. 890) is, for instance, captured in our analysis of closeness centrality. Barcelona is the 54th closest city because it hosts subsidiaries of firms located in world cities such as Paris, Chicago, Osaka, London, Munich, and Tokyo. This puts Barcelona in close proximity to nearly every city in the network. But Barcelona does not host a headquarter office of any of the 500 largest corporations in the world, while Omaha hosts three (Berkshire Hathaway, Conagra, and Union Pacific). This explains how Omaha outranks Barcelona on outdegree 26th versus 126th, while Barcelona outranks Omaha on closeness 55 th versus 99 th. We think closeness, along with betweenness, in fact captures what Taylor refers to as "strategic places where it is necessary to be" (in this issue, p. 890) and find it unfortunate that he does not consider this part of our analysis. ${ }^{5}$

\section{NETWORK OF WORLD CITIES OR WORLD CITY NETWORK?}

As could be inferred from our attention to the GaWC research that was available at the time "Power and Position in the World City System" was written, we have learned much from the astounding volume of first-rate scholarship produced by the GaWC group. ${ }^{6}$ We expect that a deeper understanding of the world city system can be developed by building on the natural complementarities of our projects. In the next section, we turn to the road ahead. But first, we must sharpen some contrasts.

Much of the GaWC research orients toward the network of world cities, while our work focuses on the world network of cities. The difference is more than semantic: the study of world cities-those cities at the center of the world network of cities-begins by selecting a "roster" of world cities, as in Beaverstock, Taylor, and Smith (1999). Then, the presence of what Taylor refers to as "global service firms" (in this issue, p. 882) in

\footnotetext{
${ }^{5}$ Taylor suggests that closeness and betweenness centrality are "inherently less interesting for understanding inter-city relations" (in this issue, p. 11) because they are calculated using symmetric, dichotomous data matrices instead of the original directed, valued data matrix. We disagree and, for the reasons detailed above, believe that they are integral to our analysis.

${ }^{6}$ As of this writing, a total of 200 research bulletins have been produced by the GaWC group (see http://www.lboro.ac.uk/gawc/publicat.html).
} 
these cities is ascertained using information from websites and other sources on the locations of corporate offices in those world cities. More recent GaWC research moves away from this city-centered sample selection toward a firm-centered approach (e.g., Taylor [2004]), but the inclusion of producer service firms is limited to those that exhibit a "global strategy," operationalized as "offices in at least 15 different cities including one or more cities in each of the prime globalization arenas: northern America, western Europe and Pacific Asia" (Taylor, Catalano, and Walker 2002, p. 2369). The selection of cities is based on the GaWC researchers' expertise and includes 315 cities: "The capital cities of all but the smallest states plus numerous other cities of economic importance from all continents" (Taylor et al. 2002, p. 2369). This manner of selecting firms and cities should result in a relatively dense, interconnected network structure. The GaWC sample selection strategy differs from ours in that we begin with the world's 500 largest corporations as ranked by Fortune magazine and collect all the available data from the Directory of Corporate Affiliations on the locations of headquarters and subsidiaries. This strategy yields data on 3,692 cities, and 29,302 firms (446 of these firms are the peak conglomerates in headquarter cities, and the other 28,856 are subsidiaries, including manufacturing plants and regional headquarters).

Our firm-centered selection of cities allows the network of cities to emerge from the data. Thus, a city like Vevey (Switzerland) emerges as an important node in the world network of cities even though it cannot be characterized as a "world city." We think places like Vevey (the headquarters of Nestle) play an important role in the world city system because large multinational enterprises located in their founding towns can tie hundreds of places into the network, which has implications for the global structure of the network. ${ }^{7}$ It is of course true that multinationals are often located in founding towns like Vevey, but it does not follow that multinationals never relocate their head offices (examples of such moves are SBC Communications from Saint Louis to San Antonio and Boeing from Seattle to Chicago). Also, our firm-centered sample selection may help guard against bias that could result from the use of website-based data on the producer-services sector. Although English is the global lingua franca, we worry about the degree to which the GaWC sample selection strategy might drive the ranking of Hong Kong over Tokyo, and the ranking of Singapore over Frankfurt.

${ }^{7}$ Other places like Vevey, Switzerland (Nestle) are Ludwigshafen am Rhein, Germany (BASF), Wolfsburg, Germany (Volkswagen), and Rochester, New York (Eastman Kodak). 
American Journal of Sociology

NEXT STEPS DOWN THE PATH(S)

We agree with Taylor that an important next step is to move beyond economic relations among cities and address the social, political, and cultural dimensions of the world city system. Both our project (Alderson and Beckfield 2002) and Taylor's (2004) are moving in that direction. In the spirit of Taylor's comment, we want to conclude our reply by suggesting more ways that our parallel paths might be brought together.

First, we should consider the role of economic sector in structuring the world city system. As Taylor notes, several discrepancies between his results and ours can be accounted for by functional differences between the firms sampled (e.g., the prominence of Vevey in our data results from the inclusion of food-sector giant Nestle). Taylor argues for attention to the producer-services sector because it represents the avant-garde of global economic activity (in this issue, p. 892), but we think this is an important empirical question that should not be foreclosed. While it could be the producer-services sector that leads the way in binding cities into a global network, it is likely that the industrial sector also constructs connections of control among cities, as firms like Volkswagen establish manufacturing operations in places like Puebla (Mexico).

Second, we should study the extent to which command and control attracts global services. Inspired by Sassen's work on the practice of control enabled by firms in the advanced producer service sector (Sassen 2001), GaWC research focuses on the leading firms in accounting, advertising, banking and finance, insurance, law, and management consulting (Taylor et al., 2002). Taylor argues that these firms are attracted to major cities in part by the presence of specialized markets for their services and a client base of multinational enterprises (in this issue, p. 8). But whether and how much this happens is an empirical question. Splitting the world city network into a network of producers and producer services would allow for an assessment of this attraction. Splitting the network in this way would also show how well the "command dimension" of the world city network maps to the "business service dimension," thus addressing the basic conceptualization of the world city.

Third, we should account for variation in the level of firms' presence in cities. One of the key advantages of the GaWC data matrix is its sensitivity to the relative importance of firm $j$ 's office in city $i$. Although this procedure raises specific coding questions (e.g., counting headquarters as "5" and regional headquarters as "4" arguably understates the control exercised in headquarter cities and "flattens" the structure of the network), it does add nuance to the measurement of structure. For many of the world's 500 largest firms, our data source, the Directory of Corporate Affiliations, does provide information on hierarchical structures within 
firms, and this could be used to measure more sensitively the presence of many kinds of firms in cities. Moreover, with such information, we could apply Taylor's interlocking network model to our data.

Fourth, we should examine change in global city relations. Many of the more provocative claims of world city researchers concern system dynamics rather than statics (Alderson and Beckfield 2004, p. 848), and even the argument that producer-service firms have created global service networks of world cities implies that the network has changed since the 1980s (see Taylor, in this issue, p. 8). As we mentioned in the work under discussion here, we are analyzing data on locations of multinational enterprises from the early $1980 \mathrm{~s} .{ }^{8}$ We think an analysis of the producerservices network from an earlier period is also essential.

Finally, we should move to address the impact of position in the world city system. The ultimate aim of world city research should be to show, on the one hand, how position in the world city system matters for cities and their residents, and on the other hand, how cities matter for globalization. Attention to the relative effects of cities' embeddedness in the producer-services and corporate control networks would mark a real advance.

University of Chicago

JASON BECKFIELD

Indiana University

Arthur S. Alderson

\section{REFERENCES}

Alderson, Arthur S., and Jason Beckfield. 2002. "Globalization and the Centralization of Power in the World City System." Paper presented at the XVI World Congress of Sociology, Brisbane, Australia.

- 2004. "Power and Position in the World City System." American Journal of Sociology 109:811-51.

. In press. "Globalization and the World City System: Preliminary Results from a Longitudinal Data Set." In Cities in Globalization: Practices, Policies, and Theories, edited by Peter Taylor, Ben Derudder, Piet Saey, and Frank Witlox. London: Routledge.

Bearden, James, and Beth Mintz. 1987. "The Structure of Class Cohesion: The Corporate Network and Its Dual." Pp. 187-207 in Intercorporate Relations: The Structural Analysis of Business, edited by Mark S. Mizruchi and Michael Schwartz. New York: Cambridge University Press.

Beaverstock, Jon V., Peter J. Taylor, and Richard G. Smith. 1999. "A Roster of World Cities." Cities 16:445-58.

\footnotetext{
${ }^{8}$ The first results of this effort will appear in Alderson and Beckfield (in press).
} 


\section{American Journal of Sociology}

Borgatti, Stephen P. and Martin G. Everett. 1997. "Network Analysis of 2-Mode Data." Social Networks 19:243-69.

Breiger, Ronald L. 1974. "The Duality of Persons and Groups." Social Forces 53: 181-190.

Burris, Val. 2004. "The Academic Caste System: Prestige Hierarchies in PhD Exchange Networks." American Sociological Review 69:239-64.

DiMaggio, Paul J. 1986. "Structural Analysis of Organizational Fields." Pp. 335-70 in Research in Organizational Behavior, edited by Barry Staw and Lawrence Cummings. Greenwich, Conn.: JAI Press.

Fernandez, Roberto M., and Roger V. Gould. 1994. "A Dilemma of State Power: Brokerage and Influence in the National Health Policy Domain." American Journal of Sociology 99:1455-91.

Hannan, Michael T., and John Freeman. 1989. Organizational Ecology. Cambridge, Mass.: Harvard University Press.

Kim, Sangmoon, and Eui-Hang Shin. 2002. "A Longitudinal Analysis of Globalization and Regionalization in International Trade: A Social Network Approach." Social Forces 81:445-68.

McPherson, J. Miller. 1982. "Hypernetwork Sampling: Duality and Differentiation among Voluntary Organizations." Social Networks 3:225-49.

Meyer, David R. 1984. "Control and Coordination Links in the Metropolitan System of Cities: The South as a Case Study." Social Forces 63:349-62.

Moreno, J. L. 1934. Who Shall Survive? Washington, D.C.: Nervous and Mental Disease Publishing.

Padgett, John F. and Christopher K. Ansell. 1993. "Robust Action and the Rise of the Medici, 1400-1434." American Journal of Sociology 98:1259-1319.

Powell, Walter W., Douglas R. White, Kenneth W. Koput, and Jason Owen-Smith. 2005. "Network Dynamics and Field Evolution: The Growth of Interorganizational Collaboration in the Life Sciences." American Journal of Sociology 110:1132-1205.

Sassen, Saskia. 2001. The Global City: New York, London, Tokyo, 2d ed. Princeton, N.J.: Princeton University Press.

Simmel, Georg. 1964. Conflict and the Web of Group Affiliations. New York: Free Press.

Smith, David A., and Douglas R. White. 1992. "Structure and Dynamics of the Global Economy: Network Analysis of International Trade 1965-1980." Social Forces 70: 857-93.

Snyder, David, and Edward Kick. 1979. "Structural Position in the World System and Economic Growth, 1955-1970: A Multiple-Network Analysis of Transnational Interactions." American Journal of Sociology 84:1096-1126.

Stinchcombe, Arthur L. 1965. "Social Structure and Organizations." Pp. 142-93 in Handbook of Organizations, edited by James March. Chicago: Rand McNally.

Taylor, Peter J. 2004. "Leading World Cities: Empirical Evaluations of Urban Nodes in Multiple Networks." GaWC Research Bulletin no. 146. Globalization and World Cities Study Group and Network.

— In this issue. "Parallel Paths to Understanding Global Intercity Relations." American Journal of Sociology, vol. 112, no. 3.

Taylor, Peter J., Gilda Catalano, and David R. F. Walker. 2002. "Measurement of the World City Network." Urban Studies 39:2367-76. 